\title{
The Fundamentals of Financial Forecasting Condition of Oil Production Enterprise
}

\author{
${ }^{1}$ University of Kufa, P.O Box 21, Kufa, Najaf Governorate, Iraq \\ ${ }^{2}$ Ural State University of Economics, 620144 Ekaterinburg, Russia \\ ${ }^{3}$ South Ural State University, 454080 Chelyabinsk, Russia \\ *Corresponding author. Email: najafahmed7@gmail.com
}

Ahmed Abedi ${ }^{1,2, *}$ Leonid Zaionchik ${ }^{3}$

\begin{abstract} stochastic, trend extrapolation methods). environment and industry in the long term. the regression analysis

Over the past five years and the beginning of 2020, with the advent of the Karon virus, the Russian and Iraqi oil and gas market had to face serious difficulties due to falling oil prices, as a result of which the financial stability of this sector and profitability decreased. In general, all this negatively affected the economy of the country as a whole, a decrease in competitiveness.

So it is Not only the analysis of financial and economic activity is important for evaluating the financial results but also the enterprise's financial forecasting, which helps to assess the financial prospects for the future and plan the future actions based on the results obtained as well as to work out recommendations to improve the financial performance[5].

Forecasting methods can be divided into four groups [4]:

1- expert evaluation method;

2- deterministic methods (the proportional method and the balance model);

3- stochastic methods (simple dynamic analysis, multivariate regression analysis, autoregressive dependencies);

4- trends extrapolation method.
\end{abstract}

The forecasting financial condition of the enterprise aims to assess financial prospects for the future period, based on the results obtained, plan future actions and recommendations for improving financial performance. As such, there are no separate approaches to forecasting exactly the financial condition of an oil producing company, there are only separate methods, there are 4 groups of them (expert estimation methods, deterministic,

A method for predicting the financial condition of an oil producing enterprise is proposed. Of the existing methods, a regression analysis method was chosen because it considers the forecast and changes in the

Keywords: coefficient, analysis, methods, assessment of financial, financial forecasting, forecasting financial,

To forecast the financial standing of the oil production company it is suggested to use the regression analysis method as it helps to make mid and long-term forecasts.

For oil industry in the light of fuel price fluctuations the short-term analysis will not be able to introduce the meaningful results so the forecast in the long term seems to be the most effective.
It will help to establish changes in industry environment and assess the impact degree of these changes to the studied financial indicators. The regression analysis is also performed for such complex structural objects as investment volume, profit and sales.

For oil industry it is necessary to make the analysis in the following important indicators:

- revenue;

- net profit;

- liquidity (current and quick liquidity ratios);

- debt coverage ratio;

- cost effectiveness.

The regression analysis method is the most simple, accurate and effective for the analysis of the current assets value and it gives the possibility to forecast one variable by changing other [3] .

Let us forecast the production volumes with the regression analysis method, which will help to determine future profit and revenue.

The dependence of current assets on the production volume is calculated by the following formula:

$$
\mathrm{Q}=\mathrm{a}+\mathrm{bX}
$$

where $\mathrm{Q}$ is the magnitude of the production volume; $\mathrm{a}$ is the intersection point of the line with the $\mathrm{Y}$ axis; $\mathrm{b}$ is the slope with the regression line; $\mathrm{X}$ is the value of the current assets.

Using the following formulae, we find $\mathrm{a}$ and $\mathrm{b}$ :

$$
a=\bar{Q}-b \bar{X}
$$




$$
b=\frac{\sum_{i=1}^{n}\left(X_{i} Q_{i}\right)-\left[\sum_{i=1}^{n} X_{i} \sum_{i=1}^{n} Q_{i}\right]}{n \sum_{i=1}^{n} X^{2}-\left[n \sum_{i=1}^{n} X\right]^{2}}
$$

where $\mathrm{n}$ is the number of observations; $\mathrm{Q}$ is the arithmetic mean of production volumes; $\mathrm{X}$ is the arithmetic mean of the current assets.

To find $\mathrm{Q}$, the production value for the observation period should be divided by the number of observations.

To find $\mathrm{X}$, the current assets value for the observation period should be divided by the number of observations.

An example of the regression equation. Let us define the linear dependence between the current assets and the production volume.

Let us find coefficients $a$ and $b$ :

$\mathrm{a}=86384,2104, \mathrm{~b}=0,3744$. The regression equation will be as follows:

$Q=86384,2104+0,3744 X$.

Let us assume that the forecast current assets value for the analysed period is 88907 roubles. Hence, according to the regression equation the forecast production volume will be 119670.99 roubles.

Determining whether a given regression equation can be used for the enterprise, it is necessary to calculate the quality and reliability parameters such as the determination coefficient and the foresight average error mean.

The determination coefficient is the most accurate reflecting the share of the change in the production volume. It ranges from 0 to 1 . The closer its value to unity is, the more accurate the regression equation reflects the reality_[6]. where Qt is the actual production volume in t year; Qtp the estimated production volume with the use of the calculated regression equation.

The average forecast error is calculated as follows:

$$
S_{e}=\sqrt{\frac{\sum_{i=1}^{n}\left(Q_{i}-Q_{t}^{p}\right)^{2}}{n-2}} .
$$

If the determination coefficient is far from unity then other methods should be used to increase the accuracy.

To calculate the determination coefficient and the average forecast error we use the following tables and formulae:

$$
S_{e}=\sqrt{\frac{\sum_{i=1}^{n}\left(Q_{i}-Q_{t}^{p}\right)^{2}}{n-2}}=\sqrt{\frac{416627251}{8-2}=8332,94}
$$

In the above example the determination coefficient is equal to 0.1767 . Since the value is far from unity it is necessary to use other methods for calculation. According to the equation the deviation is 8332.94 roubles, that is, the obtained value of the production volume, which is 119670.99 roubles, may deviate from it by 8332.94 roubles both upward and downward.

\begin{tabular}{|l|c|c|c|c|c|}
\hline \multicolumn{1}{|c|}{ Time period, $\mathbf{t}$} & $\begin{array}{c}\text { Production } \\
\text { volume, Q }\end{array}$ & $\begin{array}{c}\text { Current } \\
\text { assets } \\
\text { value, } \mathbf{X}\end{array}$ & $\begin{array}{c}\text { Evaluated } \\
\text { sales volume }\end{array}$ & $\begin{array}{c}\text { Squared } \\
\text { absolute } \\
\text { deviation }\end{array}$ & $\begin{array}{c}\text { Squared } \\
\text { deviation } \\
\text { from the mean }\end{array}$ \\
\hline First quarter of 2018 & 112300 & 65302 & 110832,044 & 2154894,7 & 67535 \\
\hline Second quarter of 2018 & 121506 & 69872 & 112542,9656 & 80335986 & 89602789,5 \\
\hline Third quarter of 2018 & 118509 & 56230 & 107435,6588 & 122618885 & 41846343,8 \\
\hline Fourth quarter of 2018 & 95860 & 54931 & 106949,3378 & 122973413 & 261796445 \\
\hline First quarter of 2019 & 102980 & 68790 & 112137,8853 & 83866862 & 82085865 \\
\hline Second quarter of 2019 & 113567 & 75462 & 114635,7559 & 1142239,1 & 2331347,3 \\
\hline Third quarter of 2019 & 115691 & 74990 & 114459,048 & 1517705,7 & 13328888,3 \\
\hline Fourth quarter of 2019 & 115908 & 82654 & 117328,3046 & 2017265,3 & 14960457 \\
\hline Total & & & & 416627251 & 506019670,9 \\
\hline Determination coefficient & & & & & 0,1767 \\
\hline
\end{tabular}

The determination coefficient is calculated by the following formula (provided that there is one independent variable in the regression equation):

$$
R^{2}=1-\frac{\sum_{i=1}^{n}\left(Q_{i}-Q_{t}^{p}\right)^{2}}{\sum_{i=1}^{n}\left(Q_{i}-\overline{Q_{t}}\right)^{2}}
$$

Hence, the risk of the forecast value should be calculated by the following formula:

$$
\mathrm{Rf}=\mathrm{Se}: \mathrm{Fp},
$$

where Se is the average forecast error; Fp is the forecast value of the parameter calculated with the help of the regression equation.

$\mathrm{Rf}=8$ 332,94 : $119670,99=0,0696$. 
Thus, the probability of the forecast value is $0,0696(1-0,696) \cdot 100=93,04 \%$.

Now, having forecast the volume of sales by the regression equation, we can calculate the direct dependence between the current assets and the result of their use.

Revenue and the profit from sales are the very things that are important for oil industry, as they help to control the indicators of turnover and business activity [7].

The next forecasting approach which is optimal for oil companies is the forecast based on the financial statements. The main balance sheet equation is the following:

$$
\mathrm{N}-\mathrm{CA}+\mathrm{CA}=\mathrm{OE}+\mathrm{L}+\mathrm{CI}
$$

where N-CA - non-current assets, CA - current assets, $\mathrm{OE}$ Owner's equity, L - Loans and credits, CI - creditor indebtedness.

It means that assets should be equal to liabilities.

Stage 1. Initial data. The indicators of the balance sheet, the Report on financial results are taken as initial data for the basis[10].

Stage 2. Calculation of the coefficients for unit costs, turnover time of the current assets and accounts payable.

The unit costs coefficient:

$$
\text { C_UC }=\mathrm{C}: \mathrm{SV} \text {, }
$$

where $\mathrm{C}$ is the costs; $\mathrm{SV}$ is the sales volume.

The turnover period of the current assets (in days) is calculated by the following formula:

$$
\mathrm{C}_{-} \mathrm{CA}=(\mathrm{CA}: \mathrm{SV}) \cdot \mathrm{T} \text {. }
$$

The payable turnover period is calculated by the formula:

$$
\mathrm{C}_{-} \mathrm{CI}=(\mathrm{CI}: \mathrm{SV}) \cdot \mathrm{T} \text {. }
$$

Stage 3. Forecast of the sales volume. This parameter is calculated by the method given above. Either it is necessary to choose other method to forecast the sales volume[1].

Stage 4. Calculation of the forecast coefficients in the next period. For the forecast value of the unit costs it is possible to set the planned value of the parameter, which shows, what percentage should change the unit costs value. For example, due to the specific measures it is possible to reduce the costs by $1 \%$ (and $\mathrm{C}$ forecast. $=1 \%$ ).

Stage 5. Forecast aggregate balance sheet. Aggregate balance sheet is a simplified form of the balance sheet, which includes the following parameters at the beginning and end of the year [2]:

Assets are the most liquid assets (p. 1250) + Quick assets (p. $1230+1240)+$
+ Slow assets (p. $1210+1220+1260)+$ Fixed assets (p. 1100);

Liability is the most accrued liabilities (p. 1520) + Shortterm liabilities (p. $1510+1540+1550)+$ Long-term liabilities (p. 1400) + Permanent liabilities (p. $1300+1530$ ). In order to forecast the costs, we need information on variable costs, which can be calculated by the regression analysis of the records from the prior periods or any other method. Let us set them by the formula:

$$
\mathrm{C}_{\mathrm{F}}=\mathrm{C}_{-} \mathrm{UC}_{\mathrm{F}} \cdot \mathrm{SV} \text {. }
$$

In case the costs are divided into individual elements, they should be forecast as well.

Let us calculate the forecast retained profits by the formula:

$$
\mathrm{RP}_{\mathrm{F}}=\mathrm{SV} \mathrm{F}_{\mathrm{F}}-\mathrm{C}_{\mathrm{F}}
$$

Forecast of non-current assets:

$$
\mathrm{N}-\mathrm{CA}_{\mathrm{F}}=\mathrm{N}-\mathrm{CA} \mathrm{n}+\text { Investments }- \text { Amortization }- \text { Sales of N-CA. }
$$

The current assets forecast is calculated by the formula:

$$
\mathrm{CA}_{\mathrm{F}}=\left(\mathrm{C}_{-} \mathrm{CA}_{\mathrm{F}} \cdot \mathrm{SV} \mathrm{F}_{\mathrm{F}}\right): \mathrm{T} \text {. }
$$

The accounts payable forecast is the following: Investments in current assets rise with the sales growth, the current assets decrease when the sales are decreasing. Equity is calculated by the formula[8]:

$$
\begin{gathered}
\mathrm{OE}_{\mathrm{F}}=\mathrm{OE}_{\mathrm{n}}: \mathrm{T} ; \\
\mathrm{CI}_{\mathrm{F}}=\left(\mathrm{C}_{-} \mathrm{CI} \mathrm{F} \cdot \mathrm{SV} \text { F }\right): \mathrm{T} .
\end{gathered}
$$

In the forecast period the equity capital increases by unappropriated retained earnings:

$$
\mathrm{OE}_{\mathrm{F}}=\mathrm{OE}_{\mathrm{n}}+\mathrm{RP}_{\mathrm{F}}
$$

Here you can see the connection between the report on the financial standing of the company and the balance sheet: the capital increases by the retained earnings.

The forecast of loans and credits is calculated by the formula:

$$
\mathrm{L}_{\mathrm{F}}=\mathrm{L}_{\mathrm{n}}+\text { Take }_{\mathrm{F}}-\text { Refund }_{\mathrm{F}} .
$$

To calculate this information, you will have to use additional sources since these values are not in the reports. When returning old debts without taking new ones, this indicator will be zero.

Stage 6. Feasibility assessment. Assets should be equal to liabilities for the forecast balance. However, it may turn out that this equality does not remain, then it is necessary to 
[2] A. Krylov. Aggregated balance,[Electronic resource], AnFin.ru, 2013.

DOI: http://anfin.ru/agregirovannyj-balans/

[3] A. Kudinov. Forecasting of the Financial Standing of Enterprise and the Results of Industrial and Commercial Enterprises] [Electronic resource]//ITEAM

DOI:https://iteam.ru/publications/finances/section_11/artic le_1275

not be supported by the sufficient financing source, which makes the plan impractical.

If the need for financing is above zero, then the financial plan is impractical, it is necessary to estimate the reserves to improve the internal efficiency. In this case, we should follow stage seven.

Stage 7. Control actions design. We proceed to this stage if NAF (need for additional financing) is above zero. It is necessary to attract additional funds:

$$
\text { Extras. resources }=\max \left(0, \mathrm{NAF}_{\mathrm{F}}\right)
$$

To balance assets and liabilities we can attract outward investments. If the company does not have the opportunity to attract them, you can use its internal reserves. An increase in retained earnings will result in decrease in unit costs. It is possible to shorten the financial cycle by reducing the terms of the current assets turnover or by the account payable turnover increase. These measures can be considered as domestic investments.

Next, we calculate the adjust value of the forecast coefficient:

$$
\mathrm{C}_{\text {_forecast }} \mathrm{F} \text { new } \mathrm{C} \mathrm{C}_{-} \text {forecast } \mathrm{F}+\mathrm{u}_{-} \mathrm{C}_{-} \text {forecast }
$$

We can also use the balance sheet adjustment.

- Non-current assets - a change of the cost of the capital stock and other non-current assets corresponds to their sale or purchase and commissioning;

- Total equity - additional issue of the share capital;

- Loans - a change in loans corresponds to taking and repayment of a loan.

Following that we return to Stage 4 or Stage 5.

Stage 8. Completion of the calculation. This algorithm is perfectly used for oil companies, where reporting is the reflection of technological business processes [9].

Thus, the use of financial forecasting helps to assess the financial standing of the company and determine the main vectors to improve its performance.

\section{REFERENCES}

[1] A. B. Richard, C. Stewart, Myers Principles of Corporate Finance: translated from English - Moscow: Olymp Business, 2004.
[4] E.O. Rumyantsev. Methods of Forecasting the Financial Standing of Enterprises]. Russian Journal of Entrepreneurship, 2008, Volume 9, No. 5, pp. 64-68.

[5] I.A. Ivanyuk Assessment of the Global Crisis Impact on the Financial Stability of Oil and Gas Companies Molodoi Uchenii, 2016, No. 6, pp. 435-437 DOI: https://moluch.ru/archive/110/26854/

[6] L.S. Khromtsova. Correlation and Regression Analysis of the Main Iindicators of Oil Industry [Electronic resource], CyberLeninka, 2007

DOI: https://moluch.ru/archive/110/26854/

[7] N.A. Khromykh. Possibilities of applying methods of regression analysis in forecasting current assets of an economic entity [Electronic resource], Cyberleninka. Economic analysis: theory and practice. - No. 10 (265). 2012.

DOI: https://cyberleninka.ru/article/n/vozmozhnostiprimeneniya-metodov-regressionnogo-analiza-priprognozirovanii-oborotnyh-aktivovhozyaystvuyuschego-subekta

[8] O.I. Dranko. Financial Forecasting Model and Scenarios of Domestic Investments: Control Sciences. Moscow: Institute of Control Sciences RAS, 2007

[9] O.I. Dranko. The methodology of industrial enterprises development management using a complex of mathematical models and forecasting methods: dis .... Dr. tech. Sciences: Russia, Chelyabinsk, 2018, 275 p.

[10] V.V. Kovalev, V.V. Patrov. V.A. Bykov, How to Read the Balance: 5th edition, revised. Moscow: Finance and Statistics, 2006 